\begin{tabular}{ll}
\hline Thabiea : Journal of Natural Science Teaching \\
Program Studi Tadris Ilmu Pengetahuan Alam \\
Institut Agama Islam Negeri Kudus \\
http://journal.stainkudus.ac.id/index.php/Thabiea \\
$p$-issn: $2580-8974, e$-issn: 2655-898x
\end{tabular}

\title{
Sciencepreneurship Mahasiswa Prodi IPA pada Mata Kuliah Praktikum Biologi Dasar
}

\author{
Ulya Fawaida ${ }^{a, 1 *}$, Henry Setya Budhi ${ }^{\text {b,2 }}$, Ullum Miftaqul Zannah Gustita'iroh ${ }^{\mathrm{c}}$ \\ a,b,c IAIN Kudus, Jalan Conge Ngembalrejo No.51, Bae, Kabupaten Kudus, Jawa Tengah 59322 \\ ${ }^{1}$ ufawaida@yahoo.com*; ${ }^{2}$ henrysb@iainkudus.ac.id
}

\begin{tabular}{ll}
\hline ABSTRAK \\
\hline Kata kunci: & Pada penelitian ini dosen berusaha menumbuhkan minat berwirausaha mahasiswa \\
Sciencepreneurship & dengan menggunakan pendekatan sciencepreneurship pada mata kuliah Praktikum \\
Praktikum & Biologi Dasar. Metode penelitian ini menggunakan data kuantitatif yang di \\
Biologi Dasar & prosentasekan kemudian dianalisis dan dinarasikan. Populasi pada penelitian ini \\
& mahasiswa Tadris IPA kelas A dan kelas B yang datanya diambil secara acak, terdiri \\
& dari 25 mahasiswa. Pendekatan sciencepreneurship dapat diterapkan pada materi \\
& biotekonologi konvensional yaitu pada pembuatan tempe dan yogurt. Pada \\
& pendekatan pembelajaran ini memberikan pengalaman yang bermanfaat diantaranya \\
& selalu berpikir positif, bekerja keras dan cerdas, kerjasama tim, berfikir kritis, sikap \\
& pantang menyerah, kreatif, membuktikan proses sains dan fakta lapangan serta, \\
& menumbuhkan minat menjadi seorang entrepreur. \\
\hline
\end{tabular}
ABSTRACT

Keyword: $\quad$ Science Education Students' Sciencepreneurship in Basic Biology Practicum

Sciencepreneurship Subjects. In this study, the lecturer tried to foster interest in student entrepreneurship Practical by using the sciencepreneurship approach in the Basic Biology Practicum course. The Basic Biology method of this research is to use quantitative data in a percentage then analyzed and narrated. The population in this study were students of Natural Sciences class A and class B whose data were taken randomly, consisting of 25 students. The sciencepreneurship approach can be applied to conventional biotechnology materials, namely the manufacture of tempe and yogurt. This learning approach provides useful experiences including always thinking positively, working hard and smart, teamwork, critical thinking, unyielding attitude, being creative, proving the process of science and facts in the field and, fostering an interest in becoming an entrepreneur.

Copyright (C) 2019 Institut Agama Islam Negeri Kudus. All Right Reserved

\section{Pendahuluan}

Era globalisasi dewasa ini, entrepreneurship atau kewirausahaan memiliki peranan yang sangat penting dalam suatu perekonomian negara. Indonesia menjadi salah satu negara berkembang yang memiliki presentase penduduk berwirausaha sangat rendah dan di bawah rata-rata. Menurut data olahan Badan Pusat Statistik (BPS) pada tahun 2018 jumlah wirausaha di Indonesia baru mencapai 3,1 persen dari total penduduk usia produktif, jumlah tersebut terbilang sangat rendah dibandingkan dengan tingkat wirausaha di negara-negara maju yang mencapai 14 persen (Fisamawati, 2018). Menurut Siswono (dalam Afriadi \& Yuni, 2018) semakin rendah presentase atau indeks entrepreneurship activity (aktivitas kewirausahaan) suatu negara berdampak terhadap tingginya angka pengangguran. Hal ini dapat dibuktikan dengan tingginya angka pengangguran di Indonesia, diantaranya yang memiliki prediket sarjana.

Upaya penanggulangan pengangguran dapat dilakukan dengan merubah pola pikir mahasiswa dari mencari pekerjaan menjadi menciptakan lapangan pekerjaan (Ely Ana Kristanti, dkk, 2012). Menurut Priyanto (2009) untuk dapat menciptakan lapangan pekerjaan, harus memiliki minat dan bakat berwirausaha. 
Di sinilah peran pendidikan sangat dibutuhkan, karena pendidikan merupakan usaha sadar untuk mengubah jiwa atau pribadi dan pola pikir seseorang menuju hal yang lebih baik, salah satunya dengan menumbuhkan minat dan sikap entrepreneurship pada mahasiswa.

$$
\text { Menurut Sagoro }
$$

entrepreneurship (Kewirausahaan) adalah proses menciptakan nilai dengan mengumpulkan beberapa sumber daya manusia yang bersifat unik oleh seseorang untuk digunakan sebagai modal mengambil kesempatan bisnis yang ada atau kemampuan seseorang untuk menghasilkan barang dan jasa dengan kreativitasnya bertujuan mencari keuntungan dan kepuasan. Afriadi \& Yuni (2018) mengemukakan bahwa entrepreneurship (Kewirausahaan) adalah orang yang selalu mencari perubahan, berusaha mengikuti dan menyesuaikan perubahan itu, mampu mengambil peluang, serta berani mengambil resiko dalam setiap peluang yang di ambil.

Seorang entrepreneurship harus memiliki karakteristik sebagai berikut: 1) selalu berpikir positif, 2) bekerja keras dan cerdas, 3) disiplin, 4) komitmen tinggi dengan kemajuan usaha, 5) mandiri tanpa tergantung dengan pihak lain dalam mengambil keputusan, 6) kreatif dan inovatif (Sagoro, 2013). Sikap tersebut yang harus dimiliki oleh Mahasiswa Pendidikan Ilmu Pengetahuan Alam (IPA) dan dapat diimplementasikan pada setiap mata kuliah, salah satunya Mata Kuliah Praktikum Biologi Dasar.

Biologi yaitu ilmu yang mempelajari tentang organisme hidup dan interaksinya dengan lingkungan (Tim Biologi, 2011). Biologi merupakan salah satu Ilmu Pengetahuan Alam (IPA) yang kajiannya sangat luas, karena membahas makhluk hidup di seluruh permukaan bumi. Cakupan ilmu Biologi yang sangat luas, maka dibagi dalam beberapa cabang ilmu. Salah satu cabang Biologi yang membahas tentang mikroba yaitu mikrobiologi. Beberapa jenis mikroba yang bermanfaat untuk keberlangsungan hidup manusia.
Pembelajaran Biologi yang baik menurut Mutia (2016), diantaranya: 1) lebih penekankan pada pemahaman konsep Biologi, 2) memberikan kesempatan yang besar pada mahasiswa untuk melakukan menginvestigasi, 3) menghubungkan kosep Biologi dengan kehidupan nyata. Praktikum Biologi Dasar merupakan salah satu mata kuliah Program Studi Pendidikan IPA IAIN Kudus yang memberikan kesempatan pada mahasiswa untuk melakukan investigasi dan menghubungkan antara kehidupan yang nyata dengan pendekatan ilmiah (konsep Biologi).

Pada pembelajaran Praktikum Biologi Dasar harus dibuat model, metode dan media semenarik mungkin agar mahasiswa tertarik pada materi yang di ajarkan dan menghasilkan pembelajaran yang bermakna. Pendekatan saintifik sendiri terdiri lima pengalaman belajar pokok yaitu (1) mengamati, (2) menanya, (3) mengumpulkan informasi, (4) mengasosiasi, dan (5) mengkomunikasikan. Dalam pembelajaran di IPA ketika menggunakan pendekatan saintifik akan menjadikan pembelajaran menjadi bermakna sehingga pendidikan seumur hidup akan tercapai. Berdasarkan hal tersebut pada Mata Kuliah Praktikum Biologi Dasar menggunakan pendekatan sciencepreneurship yaitu mengintegrasikan antara sains atau konsep biologi dan kewirausahaan dengan menyesuaikan tema materi yang tepat.

Sciencepreneurship merupakan salah satu program lulusan yang ada di jurusan IPA. Hendaknya mahasiswa yang lulus tidak hanya menjadi seorang pendidik namun bisa jadi pengembang ilmu sains sebagai wirausaha. Banyak sekali materi di Prodi IPA yang dapat di manfaatkan untuk kewirausahaan salah satunya adalah materi praktikum biologi dasar, dimana dalam materi tersebut ada praktik pembuatan minuman yougurt dan praktik pembuatan tempe. Dalam pembelajaran mahasiswa dapat mempelajari tentang proses fermentasi yang ada serta mengkasi secara ilmiah melalui metode ilmiah, sehingga mahasiswa bisa menarik kesimpulan yang ada antara proses sains dan fakta dilapangan. 
Pembelajaran

dengan sciencepreneurship mengajak mahasiswa untuk berkreatifitas dalam menciptakan sesuatu. Dalam proses menciptakan sesuatu tersebut tentunya mahasiswa banyak sekali menemukan kesulitan dan hambatan yang harus mereka selesaikan sehingga kerja sama antara tim akan terjadi. Proses sainsterpreunesip mengajarkan untuk berinovasi dan berfikir kritis sebagai halnya berfikir kritis mampu mempertajam keyakinan seseorang dan akan mempengarui seseorang. Dengan sciencepreneurship diharapkan memberikan banyak pengalaman, mulai dari kemandirian mahasiswa, kerja tim, berfikir kritis, jiwa semangat pantang menyerah, dan menyiapkan mereka sedini mungkin untuk berwirausaha.

Penelitian ini bertujuan untuk menemukan tema materi praktikum yang bisa dibuat untuk sciencepreneurship dan mengetahui pelaksanaan praktikum biologi dasar pada mahasiswa IPA dengan pendekatan sciencepreneurship. Manfaat dari penelitian ini yaitu dan menemukan tema materi praktikum yang cocok untuk dikembangkan dalam praktikum biologi dasar berbasis sciencepreneurship dan memberikan pengalaman pada mahasiswa tentang proses pelaksanaan sciencepreneurship.

\section{Metode}

Metode penelitian ini adalah metode kuantitatif dengan melakukan observasi, menyebar angket pada mahasiswa. Objek penelitian ini adalah mahasiswa IPA IAIN kudus pada mata kuliah praktikum Biologi Dasar pada materi Bioteknologi Konvensional.

\section{Hasil dan Pembahasan}

Pada penelitian ini meteri Praktikum Biologi Dasar yang cocok untuk dikembangkan mahasiswa yaitu materi Bioteknologi konvensional diantaranya proses fermentasi tempe yang memanfaatkan bakteri Rhizopus microsporus dan Rizhopus oryzae dan proses fermentasi yogurt yang memanfaatkan bakteri asam laktat yaitu Lactobacillus bulgaris dan Streptococus thermophillus.

Mahasiswa melakukan praktikum pembuatan tempe menggunakan berbagai macam kacang diantaranya kacang tanah, kacang merah dan kacang kedelai dengan memanfaatkan bakteri Rhizopus microsporus dan Rizhopus oryzae dengan langkah-langkah sebagai berikut 1) Membersihkan biji kacang tanah, kacang merah dan kacang kedelai, kemudian merendam selama 12-18 jam. 2) Melepaskan kulit biji kacang tanah, kacang merah dan kacang kedelai yang telah direndam, kemudian mengukus sampai kacang lunak. 3) Menuangkan kacang yang telah direbus pada wadah bersih, kemudian ditunggu hingga kacang dingin. 4) Menaburkan ragi secukupnya sampai merata pada kacang tanah, kacang merah dan kacang kedelai. 5) Memasukkan masing-masing kacang ke dalam plastik, kemudian memberi lubang menggunakan jarum. 6) Menyimpan pada tempat yang bersuhu kamar untuk proses fermentasi selama satu atau dua hari hingga seluruh permukaan kacang tertutupi oleh jamur.

Mahasiswa juga melakukan praktikum pembuatan yogurt yang memanfaatkan bakteri Lactobacillus bulgaris dan Streptococus thermophillus dengan langkah-langkah sebagai berikut, 1) Memanaskan susu segar $1000 \mathrm{ml}$ hingga suhu $85^{\circ} \mathrm{C}$, kemudian memasukkan ke dalam toples. 2) Menunggu susu sampai suhu $45^{\circ} \mathrm{C}$, kemudian memasukkan $50 \mathrm{ml}$ yougurt plain. 3) Menutup rapat toples dan menginkubasi selama 1 malam untuk proses fermentasi.

Pada kedua praktikum yang telah dilakukan ada beberapa tim yang mengalami kegagalan pada pembuatan tempe dan yougurt. Indikasi dari kegagalan pembuatan tempe yaitu suhu ruangan tinggi (panas). Sedangkan indikasi dari kegagalam pembuatan yogurt antara lain tidak menggunakan susu murni dan yogurt plain, tetapi menggunakan susu dan yogurt dalam kemasan yang siap diminum, jarak antara penambahan susu dan yogurt plain yang kurang tepat, hal ini dikarenakan susu 
dibiarkan dingin terlebih dahulu kemudian ditambahkan yogurt plain.

Penerapan sciencepreneurship dalam pembelajaran praktikum IPA merupakan salah satu metode yang menarik bagi mahasiswa. Dari hasil penelitian di tunjukkan pada grafik 3.1 tentang ketertarikan mahasiswa terhadap sciencepreneurship, kerjasama tim, kreatifitas mahasiswa, sciencepreneurship merangsang untuk berfikir kritis, rasa pantang menyerah, proses sains, pengembangan sains sebagai wirausaha, mempersiapkan wirausahawan dari sains, ketrampilan dalam berwirausaha, pengembangan wirausaha dengan sains.

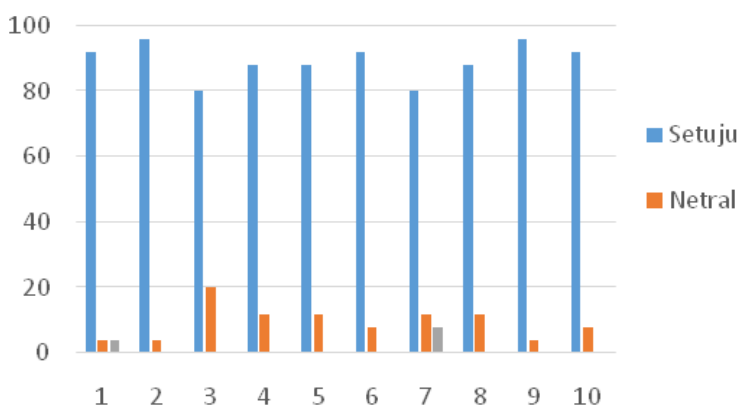

Gambar 1. Rata-rata Tanggapan Mahasiswa Mengenai Praktikum Biologi Dasar Dengan Pendekatan Sciencepreneurship

Berdasarkan rata-rata data angket di atas pada banjar 1 menunjukkan ketertarikan mahasiswa terhadap pembelajaran menggunakan pendekatan sciencepreneurship sangat tinggi yaitu mencapai 92\%. Pada pendekatan ini dapat diterapkan diberbagai mata kuliah, sehingga jiwa entrepreneurship dapat terus ditingkatkan. Hal ini dikarenakan pendidikan mempunyai peran yang penting dalam menumbuhkan motivasi wirausaha (Sukmana, 2008).

Pada grafik banjar 2 menunjukkan kerjasama tim mencapai 96\%, banjar ke 3 tentang peningkatan kreativitas mahasiswa mencapai $80 \%$, banjar ke 4 sainsterpreunership merangsang untuk berfikir kritis mencapai $88 \%$, banjar ke 5 rasa pantang menyerah mencapai $88 \%$ dan banjar ke 6 adanya proses sains mencapai 92\%. Hal ini dibuktikan pada percobaan pembuatan Yogurt terdapat beberapa kelompok yang gagal dalam pembuatannya. Dari kegagalan yang ada, kelompok tersebut mencoba menganalisis kesalahan dalam percobaan, selanjutnya mengulang kembali pembuatan yogurt sampai berhasil.

Pengalaman-pengalaman ini mengintepretasikan unsur-unsur pokok wirausahawan sukses menurut Peggy A Lambing \& Charles R Kuehl (dalam Hendro dan Chandra, 2006) diantaranya, 1) Kemampuan yaitu berhubungan dengan skill mahasiswa dalam pembutan yogurt dan tempe, 2) Keberanian yaitu ketika mahasiswa berani melakukan percobaan kembali, setelah kegagalan yang telah dialami, 3) Keteguhan hati berhubungan dengan mahasiswa yang memotivasi diri sendiri dan teman dalam satu tim untuk mencoba kembali pembuatan yogurt yang telah gagal. 4) Kreativitas di sini yaitu menemukan sesuatu yang baru atau mengembangkan sesuatu yang ada, akan tetapi poin ini belum terlihat pada Mahasiswa IPA, hal ini dibuktikan dari grafik banjar ke 2 tentang peningkatan kreativitas mahasiswa yang bersikap netral terdapat 20\%. Pada pembuatan yogurt dan tempe mahasiswa mempercayai adanya proses sains yaitu proses fermentasi dan fakta lapanngan dari percobaan yang telah dilakukan.

Pendekatan sciencepreneurship mendidik mahasiswa untuk selalu berpikir positif, bekerja keras dan cerdas, disiplin, komitmen tinggi dengan kemajuan usaha, mandiri tanpa tergantung dengan pihak lain dalam mengambil keputusan, kreatif dan inovatif .

Grafik banjar 7-10 menunjukkan adanya pengembangan sains sebagai wirausaha, mempersiapkan wirausahawan dari sains, ketrampilan dalam berwirausaha, pengembangan wirausaha dengan sains. Ratarata pada grafik menunjukkan presentase di atas $80 \%$. Presentase yang tinggi untuk menjadi entrepreneurship disebabkan oleh pembelajaran yang mendorong mahasiswa untuk memahami skill menciptakan produk wirausaha melalui penyampaian materi ajar dan praktek secara langsung. Hal ini diperkuat dengan pendapat 
Atmono (2008) bahwa pendidikan kewirausahaan yang menekankan pada praktek langsung memiliki presentasi yang besar dalam menumbuhkan dan meningkatkan minat wirausaha mahasiswa.

\section{Simpulan}

Berdasarkan hasil penelitian ini, maka dapat disimpulkan bahwa materi ajar pada mata kuliah Praktikum Biologi Dasar yang cocok dikembangkan menggunakan pendekatan sciencepreneurship yaitu materi Bioteknologi konvensional pada proses fermentasi yogurt dan tempe. Pelaksanaan pendekatan sciencepreneurship memberikan pengalaman yang bermanfaat diantaranya selalu berpikir positif, bekerja keras dan cerdas, kerjasama tim, berfikir kritis, sikap pantang menyerah, kreatif, membuktikan proses sains dan fakta lapangan serta, menumbuhkan minat menjadi seorang entrepreneur.

\section{Referensi}

Afriadi, R. \& Yuni, R. 2018. Pengembangan Jiwa Bioentrepreneur Mahasiswa Biologi. Jurnal Biolokus, 1(2), 123127.

Ana, E. K.., Siti, H.. B., Saiful, R. 2012. Pengembangan Perangkat Pembelajaran Bioentrepreneurship Pembuatan Makanan Dari Limbah Cair Pengolahan Kedelai. Journal of Innovative Science
Education, 1(2).

Atmono, D. 2008. Potensi Kewirausahaan pada Siswa SMK Negeri di kota Banjarmasin. Jurnal Didaktika, 9(1), 47-56.

Fisamawati. 2018. Fintax Fair 2019 Solusi Holistik Bagi Pengusah Muda. Diakses dari https://marketing.co.id/fintax-fair2019-solusi-holistik-bagi-pengusahamuda/. Pada tanggal 11 Agustus 2019.

Hendro \& Chandra W, W. 2006. Be a Smart and Good Enterpreneur. Jakarta: Erlangga.

Mutia, S. 2016. Tuntutan BSCS pada Pembelajaran Biologi sebagai Upaya Mempersiapkan Generasi BioEnterpreneurship Dalam Menghadapi Masyarakat Ekonomi Asean (MEA). Prosiding Seminar Nasional Biotik.

Priyanto, S. 2009. Mengembangkan Pendidikan Kewirausahaan di Masyarakat. Jurnal PNFI, 1(1), 57-82.

Sagoro, E.M. 2013. Kewirausahaan. Yogyakarta : UNY.

Sukmana, U. D. 2008. Peran Pendidikan Kewirausahaan dalam Menumbuhkan Motivasi Wirausaha. Jurnal Equilibrium, 4(8), 1-23.

Tim Biologi. 2011. Bahan Ajar Biologi Umum. Padang: UNAND. 